\title{
MODELLING ANAEROBIC DIGESTION DURING TEMPERATURE AND LOAD VARIATIONS
}

\author{
W.H. BERGLAND \& R. BAKKE \\ Department of Process, Energy and Environmental Technology, \\ University College of Southeast Norway, Norway.
}

\begin{abstract}
Experimental results and simulations based on the Anaerobic Digestion Model No.1 (ADM1) with temperature effects on kinetics were used to evaluate rate limiting steps in sludge bed anaerobic digestion (AD) during load and temperature variations. Simulations were carried out in Aquasim. The model is compared to data from a pilot experiment in a 220 liter AD sludge bed reactor treating diary manure for 16 months of various loads; $0-13 \mathrm{~kg} \mathrm{COD} \mathrm{L}^{-1} \mathrm{~d}^{-1}$ and various temperatures; $25^{\circ} \mathrm{C}, 30^{\circ} \mathrm{C}$ and $35^{\circ} \mathrm{C}$. Methane and $\mathrm{CO}_{2}$ production were monitored on-line while soluble and particulate organic carbon, $\mathrm{pH}$ and volatile fatty acids were measured on regularly collected inlet and effluent samples. Simulated overall soluble and particulate organic carbon removal, methane and $\mathrm{CO}_{2}$ production, $\mathrm{pH}$ and acetate are close to measured values while propionate is underestimated during some transitions. The fit is mainly sensitive to the composition of the feed in terms of relative amounts of lipids, proteins and carbohydrates especially at simultaneously high load and low temperature. During such conditions, the model predicts accumulation of long chained fatty acids (LCFA), suggesting that the degradation of LCFA is the rate-limiting step at low temperatures. This effect is not explained by reduced LCFA solubility at lower temperature. The model predicts that sludge bed AD efficiency on substrates with little or no LCFA is independent of temperature between $25^{\circ} \mathrm{C}$ and $35^{\circ} \mathrm{C}$ while LCFA degradation is favoured by higher temperature.
\end{abstract}

Keywords: ADM1, anaerobic digestion, rate limiting, sludge bed, temperature dependence.

\section{INTRODUCTION}

Anaerobic digestion (AD) to recover energy as methane from organic wastes can reduce greenhouse gas emissions and contribute to more sustainable waste handling.

The Anaerobic Digestion Model No.1 (ADM1) [1] is a common platform of modelling, simulations and understanding $\mathrm{AD}$, developed by the International Water Association (IWA). ADM1 was developed primarily to model digestion of sludge from wastewater treatment plants at standard process temperatures $35^{\circ} \mathrm{C}$ and $55^{\circ} \mathrm{C}$, presumed optimal for respectively meso- and thermophilic digestion.

Process heating can consume a large portion of the potential energy of organic wastes, especially in $\mathrm{AD}$ of low energy substrates, such as cow manure slurry. Implications of $\mathrm{AD}$ at $\mathrm{T}<35^{\circ} \mathrm{C}$ to reduce heat losses is therefore studied. ADM1 included temperature effects on kinetic coefficients for the biochemical processes particle disintegration, hydrolysis and substrate uptake reactions (ADM1-T) were developed for this purpose [2]. This model combined with pilot tests is used here to examine temperature effects during a wide range of loadings.

Intermediate products are measured to identify rate limiting degradation steps since it is not always obvious what is the rate-limiting step. Disintegration, hydrolysis, propionate degradation and acetoclastic methanogenesis are often considered to be possible rate limiting processes, depending on the feed composition. LCFA degradation may also be the rate limiting since it is slower than degradation of amino acids and sucrose. Hydrolysis and disintegration are often assumed rate limiting for particle rich substrates, such as manure, but this may be altered by pre-treatment. Particle rich manure filtrate, for which the rate-limiting step is unknown, is used as feed in this study. 
Other physio-chemical properties like solubility that may change when temperature change are also evaluated. The composition of the feed varies due to different feeding regimes for the cows during the year and effects of this is examined.

The model is compared to data from a 220 liter AD sludge bed reactor treating diary manure filtrate for 16 months of various loads; 0-13 $\mathrm{kg} \mathrm{COD} \mathrm{L}^{-1} \mathrm{~d}^{-1}$ with step temperature changes between $25^{\circ} \mathrm{C}, 30^{\circ} \mathrm{C}$ and $35^{\circ} \mathrm{C}$.

The main goal is to evaluate how well ADM1-T handles temperature effects in sludge bed $\mathrm{AD}$ in the upper mesophilic range by studying how the model deviates from real behaviour at three temperatures, temperature transitions and varying load. Additional aims are: (1) Evaluate temperature effects on reactions in sludge bed AD; (2) Look for limiting reaction steps for process capacity and; (3) Evaluate effect of manure feed content variations.

\section{MATERIALS AND METHODS}

An ADM1-T model using temperature-dependent kinetic parameters for both biochemical degradation steps and physico-chemical processes is compared against continuous AD using diary manure filtrate at various HRT and temperatures. The sludge retention time, SRT, is modelled using the original suggested method in ADM1, but an alternative method is also evaluated. The composition of the feed (lipids, protein and carbohydrates) together with the biodegradability of both the liquid fraction $\left(\mathrm{COD}_{\mathrm{S}}\right)$ and solid fraction $\left(\mathrm{COD}_{\mathrm{T}}-\mathrm{COD}_{\mathrm{S}}\right)$ is varied. Simulations were carried out in Aquasim.

\subsection{Model parameters}

\subsubsection{Temperature adjusted parameters in ADM1-T}

The kinetic temperature dependent parameters, $\mathrm{K}_{\mathrm{dis}}, \mathrm{K}_{\mathrm{hyd}}$ and $\mathrm{k}_{\mathrm{m}}$, for biochemical processes in ADM1-T [2] were varied with temperature in stepwise changes at $25^{\circ} \mathrm{C}, 30^{\circ} \mathrm{C}$ and $30^{\circ} \mathrm{C}$.

$\mathrm{K}_{\text {dis }}$ and $\mathrm{K}_{\text {hyd }}$ are the temperature dependent kinetic parameters for the 1st order extracellular reactions disintegration and hydrolysis (1).

$$
\rho=K_{d i s} \cdot X_{d i s} \cdot \quad \text { and } \quad \rho=K_{\text {hyd }} \cdot X_{\text {hyd }}
$$

$\rho=$ disintegration rate or hydrolysis rate of solid substrate $\left(\mathrm{kg}\right.$ COD solid substrate $\mathrm{m}^{-3} \mathrm{~d}^{-1}$ where COD = chemical oxygen demand), $X_{\text {dis }}$ and $X_{\text {hyd }}=$ solid substrate concentration that is disintegrated or hydrolysed ( $\mathrm{kg}$ COD solid substrate $\mathrm{m}^{-3}$ ), $\mathrm{K}_{\mathrm{dis}}$ and $\mathrm{K}_{\mathrm{hyd}}=$ temperature dependent kinetic parameter for disintegration or hydrolysis $\left(\mathrm{d}^{-1}\right)$.

Disintegration is typically considered the rate-limiting step for substrates containing mainly particles, while hydrolysis of proteins, lipids and carbohydrates is rate limiting in high rate digesters and then only disintegration of decaying microorganisms is accounted for [1].

Each intracellular enzyme mediated biochemical action (acidogenesis, acetogenesis, methanogenesis) (Fig. 1) is generally approximated by a Monod type saturation function as the reaction rate of substrate uptake by organism, $\rho\left(\mathrm{kg}\right.$ COD substrate $\left.\mathrm{m}^{-3} \mathrm{~d}^{-1}\right)$, as described in eqn (2).

$$
\rho=k_{m} \cdot \mathrm{X} \cdot \frac{S}{\mathrm{~S}+K_{s}} \cdot \mathrm{I}
$$

Equation (2) contains the maximum substrate uptake rate constant $\mathrm{k}_{\mathrm{m}}$ ( $\mathrm{kg}$ COD substrate $\mathrm{kg}$ COD biomass ${ }^{-1} \mathrm{~d}^{-1}$ ), $\mathrm{X}=$ biomass concentration ( $\mathrm{kg}$ COD biomass $\mathrm{m}^{-3}$ ), $\mathrm{S}=$ substrate con- 


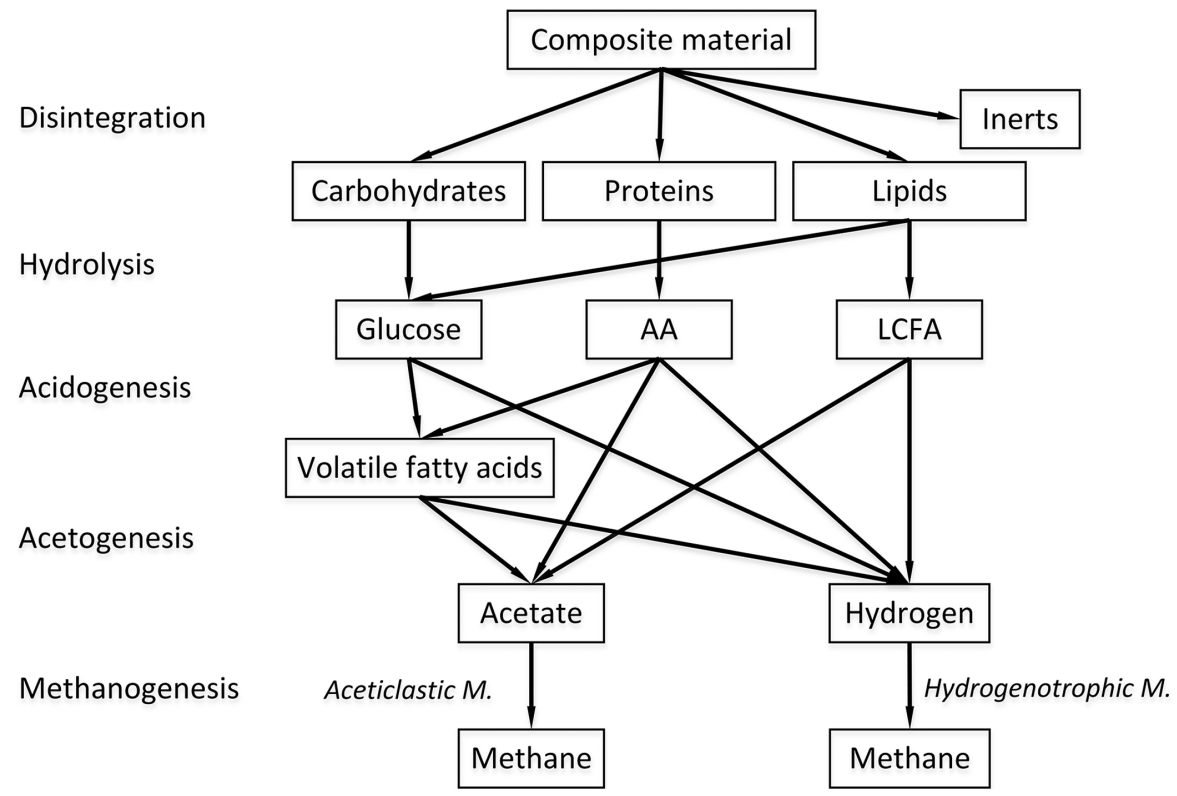

Figure 1: COD flow diagram of the Anaerobic Digestion Model No.1 (Adapted from Batstone et al. [1]) showing the biochemical reactions as arrows, all included temperature effects in AMD1-T.

centration $\left(\mathrm{kg}\right.$ COD substrate $\left.\mathrm{m}^{-3}\right), \mathrm{K}_{\mathrm{S}}=$ half saturation constant $\left(\mathrm{kg}\right.$ COD substrate $\left.\mathrm{m}^{-3}\right)$ and $\mathrm{I}=$ inhibition factor. The growth of biomass, $\mathrm{X}$, is expressed through the yield, Y (kg COD

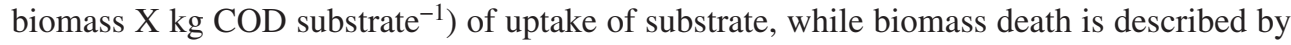
$\mathrm{K}_{\mathrm{d}}\left(\mathrm{d}^{-1}\right)$.

An ADM1-T model [2] with relative temperature effects $[3,4]$ for the degradation equations implemented is used here.

\subsubsection{SRT}

The conditions with longer SRT than hydraulic retention time (HRT) is implemented in ADM1 as SRT $=$ tres_x + HRT, recommended with tres_x $=40$ days for high rate, sludge bed reactors. The validation experiment was carried out in a sludge bed reactor, but not at a high rate, so using lower tres_x is evaluated. Another method for calculating SRT where SRT is changed proportionally to HRT (instead of having a fixed difference) using $\mathrm{f}_{\text {xout }}=\mathrm{HRT} / \mathrm{SRT}$ is suggested by Zaher et al. [5] for testing of wash out effects. This approach is also examined here since the HRT tested experimentally is low compared to typical values for such high particulate feeds.

\subsection{AD sludge bed experiment}

\subsubsection{AD reactor design operation}

The diary manure feed was from the organic milk producer Foss Farm in Skien, Norway. The manure is on average 14\% diluted by water used for washing purposes in the barn [6] making it a slurry and the handling of the slurry is described in Bergland et al. [2]. To prepare 
the manure slurry as feed it was treated in a rotating vacuum drum filter (mesh light opening of $1.4 \mathrm{~mm}$ ) to remove the coarse solids. The filtrate was used as AD feed (substrate) in this study. The diary manure AD was performed in a sludge bed reactor as an integral part of a process to generate fertilizers and biogas, as described by Haugen et al. [7]. The AD reactor is described in Bergland et al. [2]. The process had been operated for 1 year at $35^{\circ} \mathrm{C}$ before the 470 days operation reported here, allowing the culture to adapt to cow manure filtrate as substrate. The reactor was operated at the mesophilic temperatures $25^{\circ} \mathrm{C}, 30^{\circ} \mathrm{C}$ and $35^{\circ} \mathrm{C}$ at both high and low loads during this test. The load was from zero up to a load corresponding to a hydraulic retention time (HRT) of 3.6 days. The reactor was semi-continuously operated by pulse feeding with the feeding pump controlled as a binary (On/Off) device [7].

\subsubsection{Feed description}

The biodegradability and yield of the feed is reported in Bergland et al. [2]. The fractions of protein (f_pr), carbohydrates (f_ch) and lipids (f_li) in the biodegradable fraction are unknown and are therefore varied in the simulations to evaluate the effects of this fractionation (Table 1). The biodegradability fraction of dissolved organics $\left(\mathrm{COD}_{\mathrm{S}}\right)$ and biodegradability fraction of particulates $\left(\mathrm{COD}_{\mathrm{P}}=\mathrm{COD}_{\mathrm{T}}-\mathrm{COD}_{\mathrm{S}}\right)$ are also evaluated by simulations.

2.2.3 Monitoring and analysis

A comprehensive online and offline-testing scheme was used to monitor the AD reactor. Biogas production $\left(\mathrm{L} \mathrm{d}^{-1}\right.$ ), gas composition (fractions of $\mathrm{CO}_{2}$ and $\mathrm{CH}_{4}$ ), liquid flow and reactor

Table 1: Description of the feed.

\begin{tabular}{|c|c|c|c|}
\hline $\begin{array}{l}\text { Parame- } \\
\text { ter }\end{array}$ & Content & Formula & $\begin{array}{l}\text { Denomina- } \\
\text { tion }\end{array}$ \\
\hline X_c & composite & 0 & $\mathrm{~g} \mathrm{COD} \mathrm{L}^{-1}$ \\
\hline X_pr & protein & $\begin{array}{l}\text { f_pr*biodegradable fraction in particulates* } \\
\left(\mathrm{COD}_{\mathrm{T}}-\mathrm{COD}_{\mathrm{S}}\right)\end{array}$ & $\mathrm{g} \mathrm{COD} \mathrm{L}^{-1}$ \\
\hline X_li & lipid & $\begin{array}{l}\mathrm{f}_{\_} \text {li* biodegradable fraction in particulates } * \\
\left(\mathrm{COD}_{\mathrm{T}}-\mathrm{COD}_{\mathrm{S}}\right)\end{array}$ & $\mathrm{g} \mathrm{COD} \mathrm{L}^{-1}$ \\
\hline X_ch & carbohydrates & $\begin{array}{l}\text { f_ch* biodegradable fraction in particulates } * \\
\left(\mathrm{COD}_{\mathrm{T}}-\mathrm{COD}_{\mathrm{S}}\right)\end{array}$ & $\mathrm{g} \mathrm{COD} \mathrm{L}^{-1}$ \\
\hline X_I & solid inert & $\begin{array}{l}\text { Inert particulates which remains as solid* } \\
\left(\mathrm{COD}_{\mathrm{T}}-\mathrm{COD}_{\mathrm{S}}\right)\end{array}$ & $\mathrm{g} \mathrm{COD} \mathrm{L}^{-1}$ \\
\hline S_I & $\begin{array}{l}\text { soluble inert } \\
\text { (from solid) }\end{array}$ & $\begin{array}{l}\text { Inert particulates which dissolves in liquid } * \\
\left(\mathrm{COD}_{\mathrm{T}}-\mathrm{COD}_{\mathrm{S}}\right)\end{array}$ & $\mathrm{g} \mathrm{COD} \mathrm{L}^{-1}$ \\
\hline S_I & $\begin{array}{l}\text { soluble inert } \\
\text { (from liquid) }\end{array}$ & Inert in liquid* (CODs-COD $\left.\mathrm{VFA}_{\mathrm{VF}}\right)$ & $\mathrm{g} \mathrm{COD} \mathrm{L}^{-1}$ \\
\hline S_su & sugar & $\begin{array}{l}\left.\text { (Biodegradable liquid of feed }-\mathrm{COD}_{\mathrm{VFA}}\right) * \mathrm{f} \_\mathrm{ch} * \\
\left(\mathrm{CODs}-\mathrm{COD}_{\mathrm{VFA}}\right)\end{array}$ & $\mathrm{g} \mathrm{COD} \mathrm{L}^{-1}$ \\
\hline S_aa & amino acids & $\begin{array}{l}\left.\text { (Biodegradable liquid of feed }-\mathrm{COD}_{\mathrm{VFA}}\right) * \mathrm{f} \_\mathrm{pr} * \\
\left(\mathrm{COD}_{\mathrm{S}}-\mathrm{COD}_{\mathrm{VFA}}\right)\end{array}$ & $\mathrm{g} \mathrm{COD} \mathrm{L}^{-1}$ \\
\hline S_fa & $\begin{array}{l}\text { long chain fatty } \\
\text { acids }\end{array}$ & $\begin{array}{l}\left.\text { (Biodegradable liquid of feed }-\mathrm{COD}_{\mathrm{VFA}}\right) * \mathrm{f} \_ \text {li } * \\
\left(\mathrm{COD}_{\mathrm{S}}-\mathrm{COD}_{\mathrm{VFA}}\right)\end{array}$ & $\mathrm{g} \mathrm{COD} \mathrm{L}^{-1}$ \\
\hline
\end{tabular}


temperature were monitored continuously online as described by Haugen et al. [7]. Substrate and effluent samples were collected 1-2 times a week. Total chemical oxygen demand $\left(\mathrm{COD}_{\mathrm{T}}\right)$, soluble COD $\left(\mathrm{COD}_{\mathrm{S}}\right)$, total solids (TS), volatile solids (VS), total suspended solids (TSS), volatile suspended solids (VSS), $\mathrm{pH}$, alkalinity, $\mathrm{NH}_{4}{ }^{+}-\mathrm{N}$ and VFA's (acetate, propionate, butyrate, iso-butyrate, valerate, iso-valerate) were analyzed as described in Bergland et al. [8].

\section{RESULTS}

\subsection{AD sludge bed reactor data input to the model}

The methane production of the pilot AD is presented with the simulated results in Figs 2 and 3 during the given load and temperature step changes (Fig. 4). Measured substrate concentrations are in Table 2.

The simulated $\mathrm{CO}_{2}$ concentration in the biogas was as measured by setting inflow substrate $\mathrm{HCO}_{3}$ level as given in Table 2. The modelled effluent $\mathrm{pH}$ level was forced to match the measured values by finding (by "trial and error") the appropriate addition of a constant concentration of ions in the inflow substrate.

\subsection{Simulation of AD reactor}

SRT, feed composition (protein, fat and carbohydrates) and biodegradability in particulates and liquid feed is evaluated and quantified in the following sub-chapters. The biogas generated comes from $60 \%$ fat, $20 \%$ carbohydrates and $20 \%$ protein in the simulations giving the best fit with measured values. Likewise, the best-fit simulations shows that $85 \%$ of methane comes from liquid feed (CODs) and 15\% from solid feed. These best-fit simulations are presented in Figs 2, 3 and 5.

\subsubsection{Sludge retention time}

The process simulation is observed to be highly dependent on SRT, a parameter that is unknown and uncontrolled in most sludge bed reactors such as tested here.

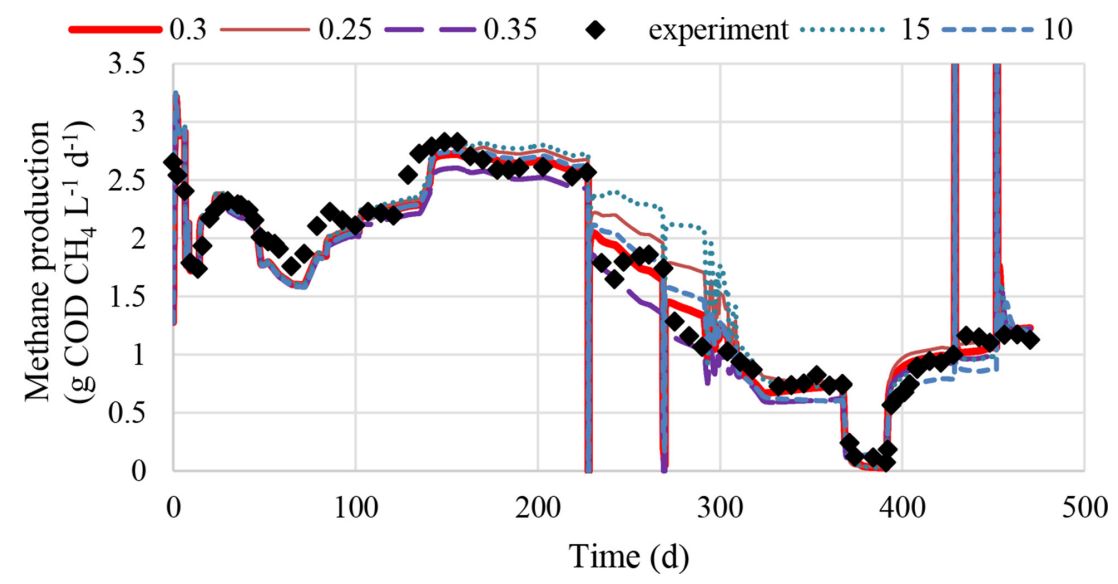

Figure 2: Methane production rate, measured and simulated, with two SRT models and the following SRT model parameters: $f_{\text {xout }} 0.25,0.3$ and 0.35 together with tres_x $=10$ and 15 . 


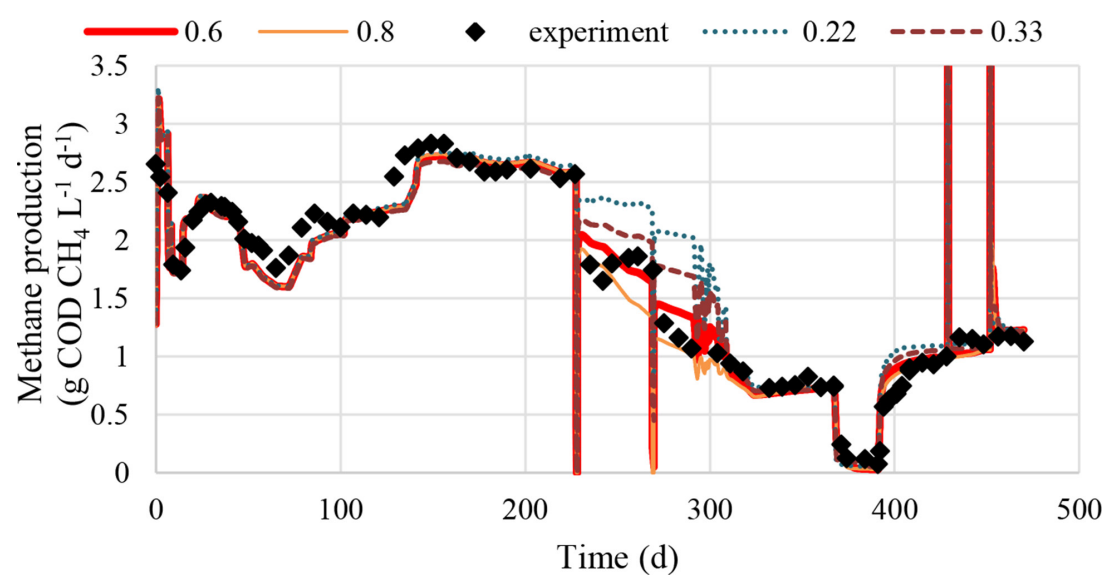

Figure 3: Methane production rate, measured and simulated, with fat content 20\%, 33\%, $60 \%$ and $80 \%$.
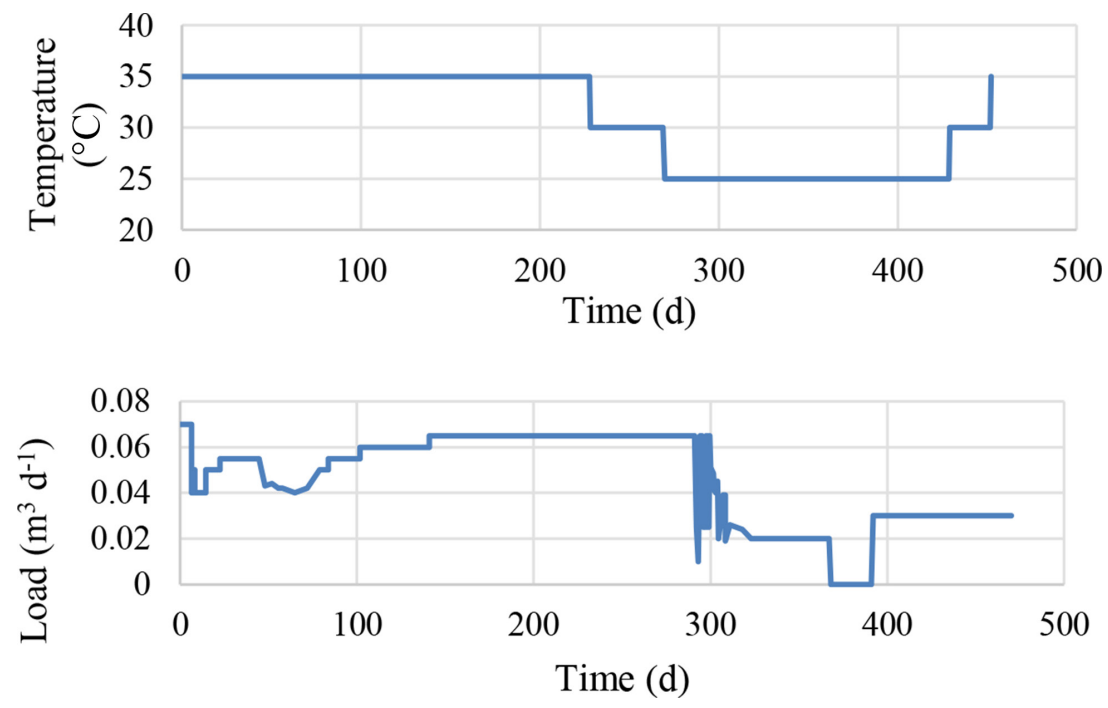

Figure 4: Temperature $\left({ }^{\circ} \mathrm{C}\right)$ and load $\left(\mathrm{m}^{3} \mathrm{~d}^{-1}\right)$ during the experiment.

Table 2: Substrate inflow content to the AD reactor, used as influent values in the simulations.

\begin{tabular}{llll}
\hline Parameter & Content & Concentration & Denomination \\
\hline COD $_{\mathrm{T}}$ & total COD & $50.9 \pm 3$ & $\mathrm{~g} \mathrm{COD} \mathrm{L}^{-1}$ \\
COD $_{\mathrm{S}}$ & soluble COD & $14.7 \pm 1$ & $\mathrm{~g} \mathrm{COD} \mathrm{L}^{-1}$ \\
S_ac & acetic acid & $3.1 \pm 0.6$ & $\mathrm{~g} \mathrm{COD} \mathrm{L}^{-1}$ \\
S_pro & propionic acid & $0.75 \pm 0.31$ & $\mathrm{~g} \mathrm{COD} \mathrm{L}^{-1}$ \\
S_bu & butyric acid & $0.18 \pm 0.10$ & $\mathrm{~g} \mathrm{COD} \mathrm{L}^{-1}$ \\
S_IC & $\mathrm{HCO}_{3}^{-}$ & $0.058-0.075$ & $\mathrm{M}$ \\
S_IN & $\mathrm{NH}_{4}+\mathrm{NH}_{3}$ & $0.062 \pm 0.006$ & $\mathrm{M}$ \\
\hline
\end{tabular}


In order to evaluate the effect of SRT, feed composition and biodegradability of particulates and liquid, the values that gave the best fit for all the intermediate products and methane production rate is used here to evaluate the effect of SRT.

SRT is calculated using tres_x $=15$ in the previous simulation [2] of this process at lower loads (days 330-470). Tres_x $=15$ is also tested in this work but did not give a good fit after the temperature reductions at high loads as it predicts higher gas production than observed. Tres_x = 10 was therefore also examined. A low tres_x, implying lower SRT than that proposed for UASB by Batstone et al. [1] (tres_x = 40) seem reasonable for the present case since HRT was higher than typical for sludge bed AD. SRT is also calculated using $f_{x o u t}$ and the best correlations were obtained in the range $f_{\text {xout }}=0.25-0.35$. These $f_{\text {xout }}$ give results comparable to tres_x of 10-15 (Fig. 2).

Using $\mathrm{f}_{\text {xout }}$ instead of tres_x improved the fit at high load with temperature reductions (e.g. days $225-300$ in Fig. 2) with SRT calculated from $f_{\text {xout }}=0.3$ being closest to the experimental values for both intermediate products and methane production. The $S R T=H R T / f_{x o u t}$ model evidently gives a better fit than SRT=HRT+tres_x during the transient conditions. This suggests that there is a stronger correlation between SRT and HRT in sludge bed processes than predicted by the SRT=HRT+tres_x model.

The active reactor biomass concentrations predicted using SRT calculated from $\mathrm{f}_{\text {xout }}=0.3$ seems quite realistic given the load applied. It is below $10 \mathrm{~g} \mathrm{COD} \mathrm{L}^{-1}$ which is $1 / 4$ of the upper limit of $40 \mathrm{~g} \mathrm{COD} \mathrm{L}^{-1}$ reactor for sludge bed $\mathrm{AD}$ operated at $>4$ times higher loads [9].

Simulated effects of SRT on methane production, acetate, LCFA and CODs concentration in the effluent may also give clues on which reactions may be the overall rate limiting steps. The observation that SRT mainly influence acetate, the reactant for most of the methane production, and LCFA, suggests that methanogenesis and LCFA degradation are the most likely overall rate limiting steps in the process investigated. These two reactions are at least especially sensitive to load transitions and SRT.

\subsubsection{Feed composition effect}

A series of four composition ratios was tested:

- $1 / 3$ of fat, carbohydrates and protein as in the original model for wastewater [1].

- $22 \%$ fat, $51 \%$ carbohydrates and $27 \%$ protein as used in a previous simulation [2] of the same process (days 330-470).

- $60 \%$ fat, $20 \%$ carbohydrates and $20 \%$ protein.

- $80 \%$ fat, $10 \%$ carbohydrates and $10 \%$ protein.

The high fat concentration cases give the best fit with the measured methane production rates, most clearly seen during the high load rate and temperature transient phases (from 230 to $300 \mathrm{~d}$ in Fig. 3). High fat content in the feed also gave the best fit for the load increase on day 390. The cases with the lowest fat content never gave significantly better fit than the high fat cases. No support is found in the literature of such high fat content in dairy manure, but hardly any relevant information is found so high fat content is assumed reasonable. $60 \%$ fat gave the best overall fit and is used in the simulations to test other parameters.

LCFA has a lower degradation rate $(\mathrm{km}=6$ in eqn $(2))$ than amino acids $(\mathrm{km}=50)$ and monosaccharide $(\mathrm{km}=30)$ that can explain the better fit at high load and low temperature. 
Table 3: Relative solubility. Calculated from [10-12].

\begin{tabular}{llll}
\hline Temperature & \multicolumn{3}{c}{ Solubility relative to $35^{\circ} \mathrm{C}$} \\
\cline { 2 - 4 } & $\begin{array}{l}\text { Average of C13-C18 LCFA } \\
\text { (not included C19-C21) }\end{array}$ & Average of 11 amino acids & sucrose \\
\hline $35^{\circ} \mathrm{C}$ & $100 \%$ & $100 \%$ & $100 \%$ \\
$30^{\circ} \mathrm{C}$ & $93 \%$ & $88 \%$ & $94 \%$ \\
$25^{\circ} \mathrm{C}$ & $86 \%$ & $77 \%$ & $88 \%$ \\
\hline
\end{tabular}

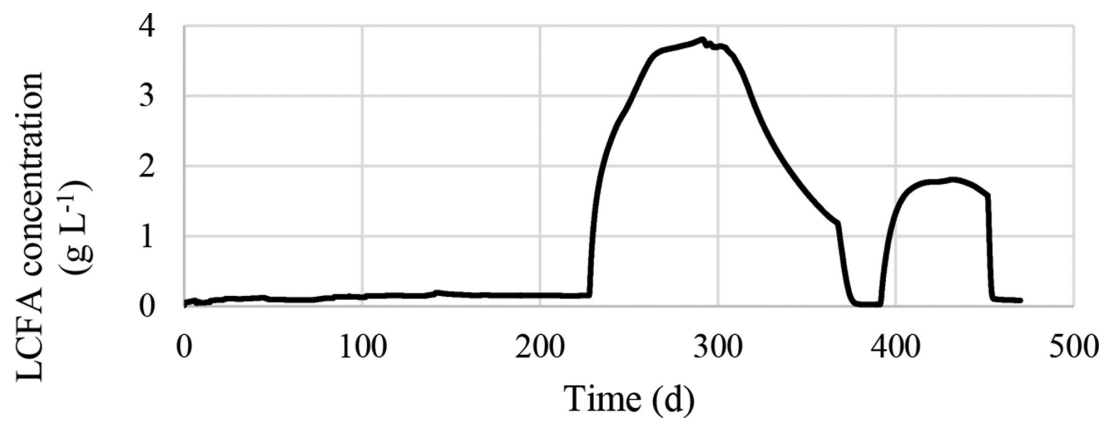

Figure 5: Simulated reactor effluent LCFA concentration during the simulation with best fit.

The relative change in solubility for LCFA, amino acids and sucrose is rather similar (Table 3). The lower degradation rate of LCFA at low temperature, therefore, cannot be explained by the difference in solubility as temperature is reduced.

The tested feed composition using $60 \%$ fat is predicting the key intermediate, acetate, best. Propionate is underestimated as in Bergland et al. [2]. Simulated overall soluble and particulate organic carbon removal and $\mathrm{pH}$ are close to measured values.

It is normally either the disintegration, hydrolysis, degradation of propionic acid or the methanogenesis that is the limiting AD reaction [1]. The relatively small fraction of particles degraded in our experiment, with $85 \%$ of methane from dissolved organics in the feed, indicates disintegration and hydrolysis as rate limiting in this case. However, the simulation with the overall best fit to experimental data shows elevated transient LCFA (Fig. 5). This suggests LCFA degradation as a rate limiting process step of the process investigated here. This is also supported by the observation that SRT, feed composition and biodegradability of particulates and dissolved feed components all influence the LCFA concentration in the effluent more than the concentrations of the other dissolved organics.

\section{CONCLUSION}

The ADM1-T, where temperature effects on kinetic coefficients for all the biochemical processes are included, yields good fit of simulated and measured methane production rate in a long term experiment where load and temperature were varied under mesophilic conditions. Simulated overall soluble and particulate organic carbon removal, methane and $\mathrm{CO}_{2}$ production, $\mathrm{pH}$ and acetate are close to measured values while propionate is underestimated. 
The main deviations between measured and modelled values, observed at simultaneously high load and low temperature, were sensitive to both SRT and feed composition. The fit is mainly sensitive to the composition of the feed in terms of relative amounts of lipids, proteins and carbohydrates especially at simultaneously high load and low temperature.

The model predicts accumulation of long chained fatty acids (LCFA) during such conditions, suggesting that the degradation of LCFA is the rate-limiting step at lower temperatures. Reduction in LCFA solubility at reduced temperature does not explain this effect. The model predicts that the sludge bed AD efficiency of substrates with little or no LCFA is independent of temperature between $25^{\circ} \mathrm{C}$ and $35^{\circ} \mathrm{C}$ while LCFA degradation is favoured at higher temperatures.

\section{ACKNOWLEDGEMENTS}

The project was supported by the Norwegian Agricultural Agency, Innovation Norway, The Research Council of Norway, Ministry of Education and Research and Telemark University College. The authors wish to thank farmer Knut Vasdal for the good cooperation in carrying out the experiment and Associate Professor Finn Haugen for the automatic process monitoring and control.

\section{REFERENCES}

[1] Batstone, D.J., Keller, J., Angelidaki, I., Kalyuzhnyi, S.V., Pavlostathis, S.G., Rozzi, A., Sanders, W.T.M., Siegrist, H. \& Vavilin, V., The IWA anaerobic digestion model no. 1 (adm1). Watet Science and Technology, 45(10), pp. 65-73, 2002.

[2] Bergland, W.H., Dinamarca, C. \& Bakke, R., Temperature effects in anaerobic digestion modeling. In Proceedings of SIMS 2015 the 56th, International Conference of Scandinavian Simulation Society, pp. 7-9, 2015. http://dx.doi.org/10.3384/ecp15119261

[3] Donoso-Bravo, A., Retamal, C., Carballa, M., Ruiz-Filippi, G. \& Chamy, R., Influence of temperature on the hydrolysis, acidogenesis and methanogenesis in mesophilic anaerobic digestion: parameter identification and modeling application. Water Science and Technology, 60(1), pp. 9-17, 2009. http://dx.doi.org/10.2166/wst.2009.316

[4] Rebac, S., Ruskova, J., Gerbens, S., Vanlier, J., Stams, A. \& Lettinga, G., High-rate anaerobic treatment of waste-water under psychrophilic conditions. Journal of Fermentation and Bioengineering, 80(5), pp. 499-506, 1995. http://dx.doi.org/10.1016/0922-338X(96)80926-3

[5] Zaher, U., Rodriguez, J., Franco, A. \& Vanrolleghem, P.A., Application of the IWA ADM1 model to simulate anaerobic digester dynamics using a concise set of practical measurements. IWA Conference on Environmental Biotechnology, Kuala Lumpur, pp. 9-19, 2003.

[6] Bergland, W.H., Dinamarca, C. \& Bakke, R., Efficient biogas production from the liquid fraction of diary manure. Renewable Energy \& Power Quality Journal (RE\&PQJ), 12, 2014.

[7] Haugen, F., Bakke, R. \& Lie, B., Adapting dynamic mathematical models to a pilot anaerobic digestion reactor. Modeling, Identification and Control, 34(2), pp. 35-54, 2013. http://dx.doi.org/10.4173/mic.2013.2.1

[8] Bergland, W.H., Dinamarca, C., Toradzadegan, M., Nordgård, A., Bakke, I. \& Bakke, R., High rate manure supernatant digestion. Water Research, 76, pp. 1-9, 2015. http://dx.doi.org/10.1016/j.watres.2015.02.051 
[9] Kleerebezem, R. \& van Loosdrecht, M., Critical analysis of some concepts proposed in ADM1. Water Science and Technology, 54(4), pp. 51-57, 2006. http://dx.doi.org/10.2166/wst.2006.525

[10] Dunn, M.S., Ross, F.J. \& Read, L.S., The solubility of the amino acids in water. Journal of Biological Chemistry, 103(2), pp. 579-595, 1933.

[11] Bober, K. \& Garus, M., RP-HPTLC Application in the investigation of solubility in water of long-chain fatty acids. Journal of Liquid Chromatography \& Related Technologies, 29(19), pp. 2787-2794, 2006.

http://dx.doi.org/10.1080/10826070601001476

[12] Alves, L.A., Almeida e Silva, J.B. \& Giulietti, M., Solubility of d-glucose in water and ethanol/water mixtures. Journal of Chemical and Engineering Data, 52(6), pp. 2166-2170, 2007.

http://dx.doi.org/10.1021/je700177n 